\title{
THE XVII ${ }^{\mathrm{TH}}$ ISA WORLD CONGRESS OF SOCIOLOGY (2010)
}

\author{
LíIIA MURINKó ${ }^{1}$
}

\section{INTRODUCTION}

For seven days sociologists from all over the world flooded the city of Gothenburg in South-Western Sweden in July 2010. About one thousand academic sessions took place in nine conference buildings with five thousand participants. Sessions ran from 8:30 a.m. till 22:00 p.m. almost every day.

The organizer of the conference was the International Sociological Association (ISA), a non-profit organization dedicated to the advancement of science in the field of sociology and social sciences. It was founded in 1949 under UNESCO and has members from 167 countries from all over the globe. The goal of ISA is "to represent sociologists everywhere, regardless of their school of thought, scientific approaches or ideological opinion, and to advance sociological knowledge throughout the world" (ISA, 2011).

The ISA holds its congress every fourth year and the meeting is its most visible activity. The last one, the 17th World Congress, took place in Gothenburg, Sweden between 11-17 July in 2010. The forthcoming XVIIIth World Congress of Sociology is scheduled for July, 2014 in Yokohama, Japan.

Besides the academic sessions, the national, regional and thematic associations of ISA also held their own meetings under the aegis of the Conference. Michael Burawoy, Professor of Sociology at the University of California (Berkeley, CA), was elected President of the ISA for the period 2010-2014. His main areas of research include work sociology and

\footnotetext{
1 Lívia Murinkó is a research fellow at the HCSO Demographic Research Institute, and a Ph.D. candidate at the Sociology Doctoral School, of the Corvinus University of Budapest; e-mail: murinko@demografia.hu. The author is grateful for the financial support of the Doctoral School that made participation at the conference possible.
} 
public sociology. He also spent four years at the Institute of Sociology of the Hungarian Academy of Sciences as a visiting professor in the ' 80 s and conducted ethnographic research in industrial workplaces.

\section{THE THEME AND SESSIONS OF THE CONFERENCE}

The main theme of the Conference was "Sociology on the move". Michel Wieviorka, the president of the ISA between 2006 and 2010, explained in his opening speech that the discipline of sociology has passed through a crisis phase that characterized the period between the 1970s and the 1990s (Wieviorka, 2010). According to him, sociology is now on the move again, because:

- the intellectual hegemony of Europe and North America is being replaced by increasing globalization, and sociological sciences are present throughout the world;

- sociologists are seeking to explore new fields of enquiry beside classical subjects;

- sociologists are addressing other disciplines within and beyond social sciences (for example, this is reflected in the fact that Professor YuanTseh Lee from Taiwan, winner of Nobel Prize for Chemistry, gave the keynote presentation);

- paradigms are being transformed and enriched;

- there is a division of opinion about the role of sociology in the public sphere.

Six main thematic areas were identified as crucial topics for the Conference (Joas, 2010):

1. The often neglected topic of "Violence and War" is of importance in an era that faces new dangers and the difficulty of mobilizing organized opposition to violence.

2. The topic of "Sustainability" has to be discussed from a sociological perspective in view of climate change and famines, as well as in terms of shortages of energy and water.

3. "Worlds of Difference" have become more important as the conventional idea of a future homogeneous modernity has been replaced by an emphasis on the role of long-standing civilizational traditions, multiple modernities and a focus on Asia.

4. The theme of "Action and Imagination" is related to new developments in biology, the transdisciplinary field of cultural studies and the growing importance of images in everyday communication and virtual realities. 
5. "Religion and Power" reflects growing skepticism from secular society in light of emergent religiously-inspired social movements, increasing interest in religious experiences and the repeated instrumentalization of religion for political purposes.

6. Due to the location and the timing of the conference, the challenges that the welfare state faces and the economic, social, political and cultural consequences of the financial crisis were identified as being additional topics of interest.

Table 1 Number of academic sessions per Research Committee (RC), Thematic Group (TG), Working Group (WG) and Thematic Session (TS)

\begin{tabular}{|c|c|c|c|}
\hline & $\begin{array}{c}\text { No. of } \\
\text { sessions }\end{array}$ & & $\begin{array}{r}\text { No. of } \\
\text { sessions }\end{array}$ \\
\hline RC32 Women in Society & 27 & RC39 Sociology of Disasters & 14 \\
\hline RC04 Sociology of Education & 20 & RC40 Sociology of Agriculture and Food & 14 \\
\hline $\begin{array}{l}\text { RC05 Racism, Nationalism and Ethnic } \\
\text { Relations }\end{array}$ & 20 & RC42 Social Psychology & 14 \\
\hline RC06 Family Research & 20 & RC44 Labor Movements & 14 \\
\hline RC16 Sociological Theory & 20 & RC52 Sociology of Professional Groups & 14 \\
\hline $\begin{array}{l}\text { RC19 Poverty, Social Welfare and Social } \\
\text { Policy }\end{array}$ & 20 & RC54 The Body in the Social Sciences & 14 \\
\hline RC21 Regional and Urban Development & 20 & $\begin{array}{l}\text { RC09 Social Transformations and Sociology of } \\
\text { Development }\end{array}$ & 13 \\
\hline RC24 Environment and Society & 20 & RC41 Sociology of Population & 13 \\
\hline RC15 Sociology of Health & 19 & RC20 Comparative Sociology & 12 \\
\hline RC34 Sociology of Youth & 19 & RC27 Sociology of Sport & 12 \\
\hline RC07 Futures Research & 18 & RC38 Biography and Society & 12 \\
\hline RC13 Sociology of Leisure & 18 & RC29 Deviance and Social Control & 11 \\
\hline $\begin{array}{l}\text { RC14 Sociology of Communication, } \\
\text { Knowledge and Culture }\end{array}$ & 18 & RC03 Community Research & 10 \\
\hline RC22 Sociology of Religion & 18 & RC17 Sociology of Organization & 10 \\
\hline RC23 Sociology of Science and Technology & 18 & $\begin{array}{l}\text { RC35 Committee on Conceptual and } \\
\text { Terminological Analysis }\end{array}$ & 10 \\
\hline RC31 Sociology of Migration & 18 & RC45 Rational Choice & 10 \\
\hline RC51 Sociocybernetics & 18 & RC46 Clinical Sociology & 10 \\
\hline RC02 Economy and Society & 17 & RC53 Sociology of Childhood & 10 \\
\hline RC11 Sociology of Aging & 17 & RC43 Housing and Built Environment & 9 \\
\hline
\end{tabular}




\begin{tabular}{|c|c|c|c|}
\hline & $\begin{array}{l}\text { No. of } \\
\text { sessions }\end{array}$ & & $\begin{array}{l}\text { No. of } \\
\text { sessions }\end{array}$ \\
\hline RC28 Social Stratification & 17 & RC49 Mental Health and Illness & 8 \\
\hline RC30 Sociology of Work & 17 & RC50 International Tourism & 8 \\
\hline RC18 Political Sociology & 16 & RC26 Sociotechnics, Sociological Practice & 7 \\
\hline RC25 Language and Society & 16 & WG01 Sociology of Local-Global Relations & 6 \\
\hline RC33 Logic and Methodology in Sociology & 16 & TG02 Historical and Comparative Sociology & 5 \\
\hline RC47 Social Classes and Social Movements & 16 & TG04 Sociology of Risk and Uncertainty & 5 \\
\hline $\begin{array}{l}\text { RC48 Social Movements, Collective Action } \\
\text { and Social Change }\end{array}$ & 15 & TG05 Visual Sociology & 5 \\
\hline RC55 Social Indicators & 15 & WG05 Famine and Society & 5 \\
\hline RC01 Armed Forces and Conflict Resolution & 14 & TG03 Human Rights and Global Justice & 4 \\
\hline RC08 History of Sociology & 14 & $\begin{array}{l}\text { TS - } 1 \text { Equal rights to work and care in the } \\
\text { Nordic countries }\end{array}$ & 1 \\
\hline $\begin{array}{l}\text { RC10 Participation, Organizational Democracy } \\
\text { and Self-Management }\end{array}$ & 14 & $\begin{array}{l}\text { TS - } 3 \text { Social determinants of health. Welfare } \\
\text { states, population health and health inequalities }\end{array}$ & 1 \\
\hline RC12 Sociology of Law & 14 & $\begin{array}{l}\text { TS - } 4 \text { Financial crisis and the changing role of } \\
\text { the state in the Nordic countries }\end{array}$ & 1 \\
\hline RC36 Alienation Theory and Research & 14 & $\begin{array}{l}\text { TS - } 5 \text { Migration as a challenge to the Nordic } \\
\text { welfare model }\end{array}$ & 1 \\
\hline RC37 Sociology of Arts & 14 & Total & 1011 \\
\hline
\end{tabular}

As its size and its pre-defined main topics would suggest, the thematic scope of the Conference was very wide. Each ISA Research Committee, Working Group and Thematic Group had the opportunity to organize their own sessions. Besides oral presentations, many sessions also involved distributed papers.

By far the most popular Research Committee was "Women in Society" with 27 sessions (Table 1). They dealt with a wide variety of sub-topics, ranging from gender discourse, sexuality, minority relations, migration and war to families and well-being. Other topics with a high number of sessions included "Sociology of Education", "Racism, Nationalism and Ethnic Relations", "Poverty, Social Welfare and Social Policy", "Regional and Urban Development", "Environment and Sociology", "Family Research" and "Sociological Theory". Health, youth, leisure activities, communication, religion, science and technology and migration also attracted great scholarly attention.

We can compare the themes of the World Congress of Sociology with the 9th Conference of the European Sociological Association that took place in Lisbon, Portugal, in September 2009 (Murinkó - Szalma, 2010). Education, 
youth, families, culture, health, environment and economy were equally popular topics at both conferences. The ISA conference, probably owing to its wide geographical scope and its predefined thematic areas, offered more sessions which dealt with such classical sociological questions as stratification, poverty, regions and urban development. The recent ISA conference also had more sessions about global problems than the ESA conference. Presentations at the World Congress of Sociology in Gothenburg reflected sociological aspects of the financial crisis as well.

\section{THE PARTICIPANTS}

The Conference had 5007 registered participants from 103 different countries (Table 2). Most of the participants arrived from the United States, followed by Germany, the UK and - not surprisingly - Sweden. Countries with more than one hundred presenters included European countries like France, Spain, Italy, Portugal, the Netherlands and the Russian Federation. Other continents were also represented at the top of the list - Japan, Brazil, Mexico, Canada, Australia and India.

Even though more than half of the presenters arrived from 38 different European countries (with 14 participants representing Hungary), the Conference was quite international (Table 3). Every fourth person came from North, Middle or South America; most of them from the United States but also from countries like Barbados and Ecuador. 14\% arrived from Asia, primarily from Japan and India. Many Asian countries were represented with only one or two presenters at the Conference. Africa and Australia and Oceania had the fewest participants: South Africa, Nigeria and Ghana were the only African countries with more than two presenters.

We can also compare the number of presenters from each country to the population of the country, thus obtaining a measure of "presentation density" which can be plotted on a map (Map 1). The host of the Conference, Sweden, had the most presenters per 1 million inhabitants (37.8). It was followed by other Scandinavian countries, as well as Luxembourg, Portugal and Switzerland. Non-European countries with the most participants per 1 million inhabitants were Israel, Australia, Canada, New Zealand and Singapore. The value of the corresponding measure for Hungary is 1.4 , which is above the average of 0.8 . 

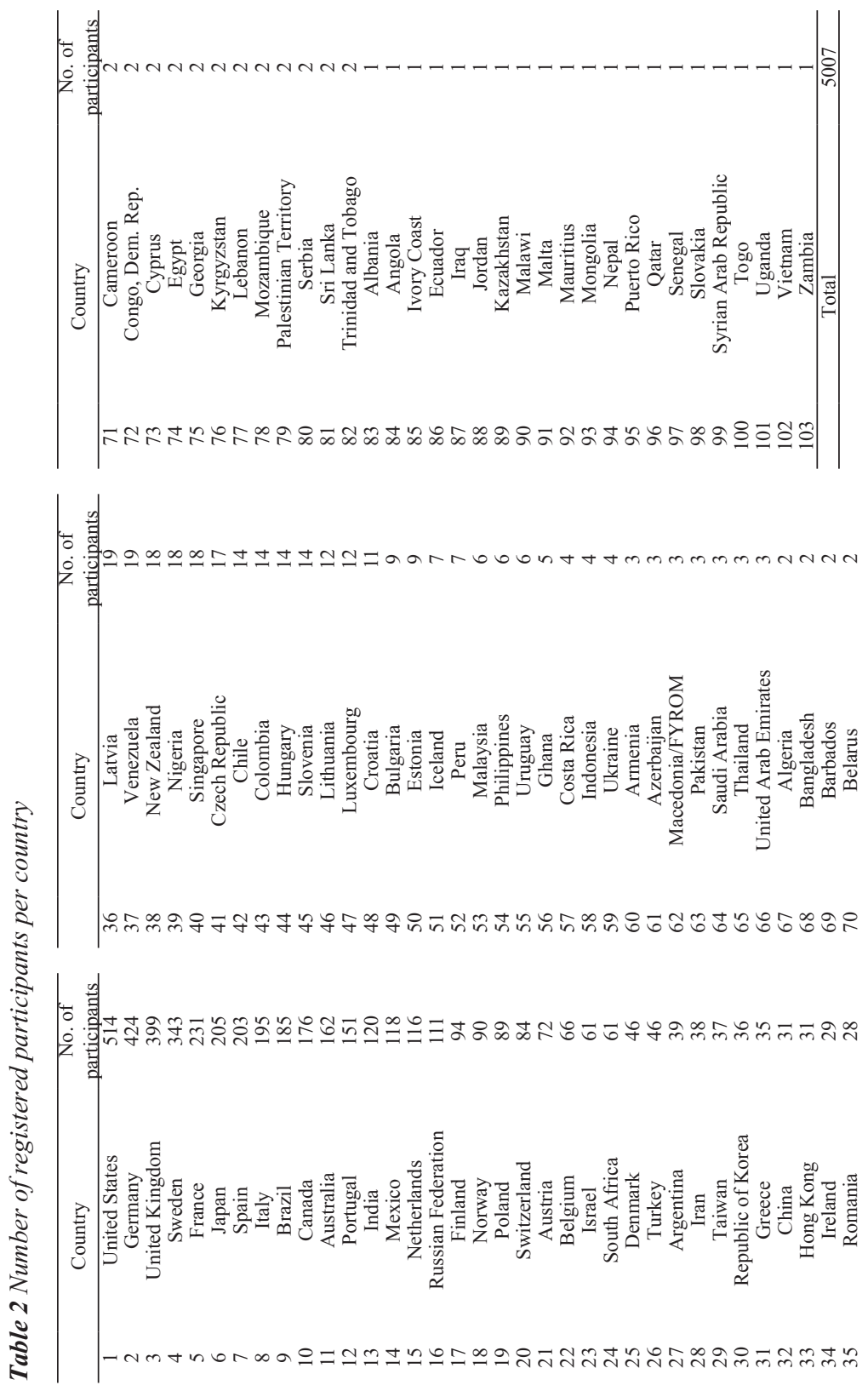
Table 3 Conference participants per continent

\begin{tabular}{lcccc}
\hline Continent & $\begin{array}{c}\text { No. of } \\
\text { participants }\end{array}$ & $\begin{array}{c}\% \text { of } \\
\text { participants }\end{array}$ & $\begin{array}{c}\text { No. of } \\
\text { countries }\end{array}$ & $\%$ of countries \\
\hline Europe & 2948 & 58,9 & 38 & 36,9 \\
The Americas & 1102 & 22,0 & 15 & 14,6 \\
Asia & 675 & 13,5 & 32 & 31,1 \\
Australia and Oceania & 180 & 3,6 & 2 & 1,9 \\
Africa & 102 & 2,0 & 16 & 15,5 \\
\hline Total & 5007 & 100,0 & 103 & 100,0 \\
\hline
\end{tabular}

Map 1 Number of participants per 1 million inhabitants

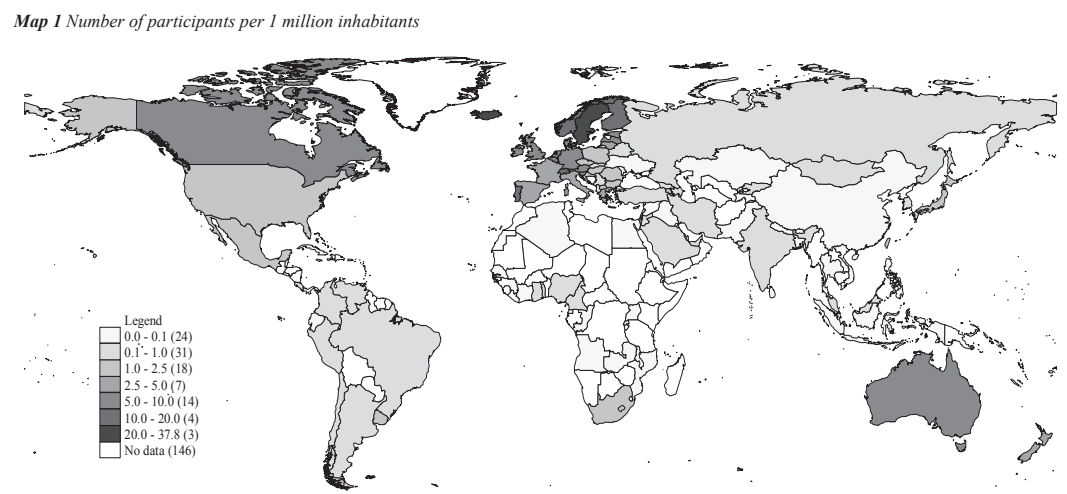

Note: The source of information on the number of inhabitants: U.S. Census Bureau (2010)

\section{REFERENCES}

ISA (2011), Statutes of the International Sociological Association. http://www.isasociology.org/about/isa_statutes.htm, Accessed: 15. 03. 2011

Joas, Hans (2010), "Welcome from ISA Vice-President for the Congress Programme", Programme: XVII World Congress of Sociology, Gothenburg, Sweden, p. 17.

Murinkó, Lívia-Szalma Ivett (2010), “The 9th Conference of the European Sociological Association: European sociology or European sociologies?",Corvinus Journal of Sociology and Social Policy Vol. 1, pp. 123-137.

U.S. Census Bureau (2010), International Data Base. http://www.census.gov/ipc/ www/idb/country.php, Accessed: 16. 03. 2011

Wieviorka, Michel (2010), "Presidential address", Presented at the XVII World Congress of Sociology, 11 July 2010, Gothenburg, Sweden 